\title{
Investigation of gas purging and cold storage impact on PEM fuel cell system performance for aeronautical applications
}

\author{
Gema Montaner Ríos ${ }^{1, *}$, Florian Becker ${ }^{1}$, Anna Vorndran $^{1}$, Christoph Gentner $^{1}$ and Syed Asif Ansar ${ }^{2}$ \\ ${ }^{1}$ German Aerospace Center (DLR), Institute of Engineering Thermodynamics, Hein-Saß-Weg 22, 21129, Hamburg (Germany) \\ ${ }^{2}$ German Aerospace Center (DLR), Institute of Engineering Thermodynamics, Pfaffenwaldring 38-40, 70569, Stuttgart (Germany)
}

\begin{abstract}
Durability of proton exchange membrane fuel cell systems under cold weather conditions is essential and a critical challenge for transportation applications. During cold storage the water remaining in the cells can freeze causing damage to the cell components. In order to avoid this degradation, fuel cells are commonly purged with dried gases during shutdown prior to its storage at subzero temperatures. This work investigates cold storage of PEMFC systems at temperatures down to $-40^{\circ} \mathrm{C}$ with the aim of developing a shutdown procedure that leads to minimal degradation due to cold storage, while meets energy efficient and time requirements of aeronautical applications. To that end, several experiments were carried out with two different stacks (a $4 \mathrm{~kW}$ liquid cooled and a $100 \mathrm{~W}$ air cooled) under a wide range of operating parameters: cathode gas, purge temperature, anode and cathode gas purge flow rates, purge time and cold storage temperature. The fuel cell performance degradation due to ice formation was measured by the polarization curves conducted prior and after every $\mathrm{F} / \mathrm{T}$ cycle. The effects of these operating parameters on the durability of the PEMFC systems under cold storage are evaluated. The obtained experimental results showed that very long purge process lead to further performance degradation at $-10^{\circ} \mathrm{C}$ than shorter process at $-40^{\circ} \mathrm{C}$, which indicates that eliminating all remained water in the cells is not only inefficient, but also lead to degradation due to the drying process. Moreover, guidelines to improve shutdown procedure for cold storage of proton exchange membrane fuel cell systems for aeronautical applications are discussed.
\end{abstract}

\section{Introduction}

Aviation represents around $2.5 \%$ of $\mathrm{CO}_{2}$ global emissions and $3.5 \%$ of global warming per year [1,2]. To move away from fossil fuel combustion to a clean aviation necessary entails the use of more environmentally sustainable technologies. Over the last years, several zero-emission energy sources and technologies have been studied and developed. Among all, the use of hydrogen is extremely promising due to its higher specific energy compared to kerosene, ammonia and batteries [3]. PEMFC systems are gaining interest for the on-board generation of electrical power on aircrafts because of its higher efficiency, less weight and lower noise.

Nevertheless, fuel cells exhibit limitations for aircraft applications which need to be overcome, such as their safe use in winter scenarios. Under sub-zero temperatures, the remaining water in the cells will freeze after shut-down causing several damages to the cell components [4]. Therefore, ensuring the durability of fuel cell systems at extremely low temperatures is essential for their deployment in aircraft applications, especially for cold operators.

As it is known from the literature no fuel cell material was damaged because of freezing temperatures down to $-40^{\circ} \mathrm{C}$, if there were no contact with liquid water [4]. Therefore, and in order to avoid degradation due to ice formation during cold storage, the stack is commonly purged with dry gases during the shut-down. However, most of the previous experimental studies about gas purging method and cold storage were carried out on single cells and at not extremely low temperatures, whereas previous numerical models didn't focus on degradation [4-8]. Thus, further investigation about the effect of purging and cold storage on the stack performance degradation at temperatures lower than $-20^{\circ} \mathrm{C}$ is needed.

In this investigation, we experimentally study the impact of the gas purging shut-down procedure and the cold storage on the PEM fuel cell system performance with two different stacks (a $4 \mathrm{~kW}$ liquid-cooled and a $100 \mathrm{~W}$ air-cooled) at temperatures down to $-40^{\circ} \mathrm{C}$. These results should assist to define an optimal shut-down procedure based on gas purging for aeronautical applications at extreme winter conditions.

\section{Experimental}

\subsection{Test bench}

This investigation was carried out with two different stacks: a $4 \mathrm{~kW}$ Hydrogenics ( 40 cells, $200 \mathrm{~cm}^{2}$ of active cell area, graphite bipolar plates and liquid-cooled) and a $100 \mathrm{~W}$ from ZBT GmbH (5 cells, $20 \mathrm{~cm}^{2}$ of active cell area, graphite bipolar plates and air-cooled). Therefore, two test benches, one for each kind of stack, were used. Details of the $4 \mathrm{~kW}$ stack test bench were presented by

\footnotetext{
$\overline{{ }^{*} \text { Corresponding author: Gema.MontanerRios@dlr.de }}$
} 
Montaner Ríos et al., and hence not repeated here [9]. The test bench used with the $100 \mathrm{~W}$ stack was developed in-house and is presented in Figure 1. The stack is fed with compressed air the cathode and with $\mathrm{H}_{2}$ the anode, whose mass flow rates are regulated: the cathode by two mass flow controllers (MFC) of $10 \mathrm{nl} / \mathrm{min}$ maximal flow rate, and the anode by one MFC of same maximal flow rate. Both gases go through a humidifier before entering into the stack. The relative humidity of cathode inlet is regulated with a humidity control valve. The anode has a hydrogen recirculation loop by a recirculation pump to reuse the residual hydrogen and for humidification, and a valve purge to regulate the pressure at anode side as well as to remove accumulated water. A blower it is used for cooling down the stack. Cell voltages are measured with the cell voltage monitoring system (CVMS) and cell temperatures with the cell temperature monitoring system (CTMS), which consists of six thermocouples connected to the six bipolar plates of the five cells. Relative humidity $(\mathrm{RH})$ of cathode inlet and outlet are measured with two relative humidity sensors, which produces reliable values at $\mathrm{RH}<90 \%$. A load with a maximal power of $45 \mathrm{~W}$ is connected to the PEMFC. The control of system components and auxiliaries, such as: blower speed, cathode relative humidity and mass flow rates are performed through a software developed in-house in LAbVIEW. For the stack cold storage was used a TT-60-375 U //logg FRYKA climate room of $(150 \mathrm{~cm} \times 50 \mathrm{~cm} \times 50 \mathrm{~cm})$, which can freeze up to $-45^{\circ} \mathrm{C}$.

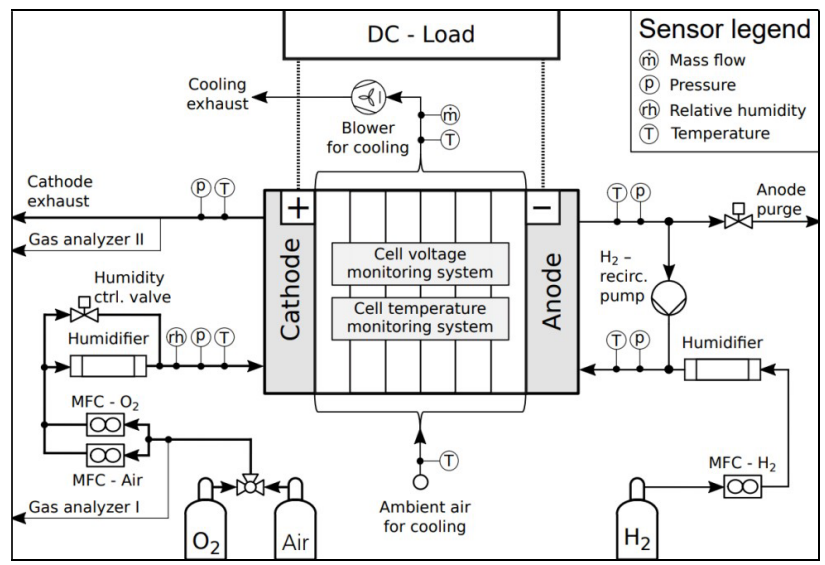

\subsection{Gas purging operating parameters}

This work studied experimentally the influence of the gas purging operating parameters on the PEMFC system performance after cold storage, first with a $4 \mathrm{~kW}$ stack at temperatures down to $-20^{\circ} \mathrm{C}$, and next with a $100 \mathrm{~W}$ stack at temperatures down to $-40^{\circ} \mathrm{C}$. The selected parameters investigated with both stacks are given in Table 1. Additionally, F/T tests conducted with the $100 \mathrm{~W}$ stack at different purge times and cold storage temperatures are listed in Table 2.

\subsection{Test protocol}

Two experimental protocols were used in this investigation, a different one for every kind of stack. However, both protocols consist of six main steps: conditioning, polarisation curve, gas purging procedure, cold storage, start-up and polarisation curve again. The major difference between both protocols is that with the $4 \mathrm{~kW}$ stack was carried out a cold start-up, while the start-up with the $100 \mathrm{~W}$ stack was carried out at room temperature. Furthermore, with the $100 \mathrm{~W}$ stack were carried out two polarisation curves after the cold storage. Following, both experimental protocols are briefly described.

\subsubsection{Test protocol used with the $4 \mathrm{~kW}$ stack}

- Conditioning test at room temperature with dry gases, but with humidification through $\mathrm{H}_{2}$ recirculation loop. - Polarisation curve was carried out at room temperature with dry gases, but with humidification through $\mathrm{H}_{2}$ recirculation loop, to get some reference points before freezing temperatures and to guarantee the same relative humidity level before purge procedure.

- Purge procedure. Stack purged with dry gases (at the cathode $\mathrm{N}_{2}$, air or synthetic air, and at the anode $\mathrm{H}_{2}$ ) to remove the remaining water before cold storage.

- Cold storage. The stack was further cooled down to the testing temperature and kept for $4 \mathrm{~h}$.

Fig. 1. PID of $100 \mathrm{~W}$ PEMFC system test bench.

Table 1. Operating parameters.

\begin{tabular}{|c|c|c|}
\hline Parameter & Value with the $4 \mathrm{~kW}$ stack & Value with the $100 \mathrm{~W}$ stack \\
\hline Cathode purge gas & $\mathrm{N}_{2}$, air, synthetic air & $\mathrm{H}_{2}$ \\
\hline Anode purge gas & $\mathrm{H}_{2}$ & 25 \\
\hline Purge temperature $\left({ }^{\circ} \mathrm{C}\right)$ & $15,40,50$ & $5,10,20$ \\
\hline Cathode purge flow rate $(\mathrm{nl} / \mathrm{min})$ & 400 & $0.375,0.75,1.5$ \\
\hline Anode purge flow rate $(\mathrm{nl} / \mathrm{min})$ & 30 & $0,45,90,300,600,1200,3600,8400,12000,14000$ \\
\hline Purge time $(\mathrm{s})$ & 180 & $-10,-20,-40$ \\
\hline Cold storage temperature $\left({ }^{\circ} \mathrm{C}\right)$ & -20 & 12 \\
\hline Cold storage time $(\mathrm{h})$ & 4 & 25 \\
\hline Start-up temperature $\left({ }^{\circ} \mathrm{C}\right)$ & -20 & \\
\hline
\end{tabular}


Table 2. F/T tests conducted with the $100 \mathrm{~W}$ stack.

\begin{tabular}{|c|c|c|c|c|c|c|c|c|c|}
\hline Test number (procedure) & 1 & 2 & $3(\mathrm{~A})$ & $4(\mathrm{~B})$ & $5(\mathrm{C})$ & $6(\mathrm{D})$ & $7(\mathrm{E})$ & $8(\mathrm{~F})$ & $9(\mathrm{G})$ \\
\hline Cold storage temperature $\left({ }^{\circ} \mathrm{C}\right)$ & -10 & -20 & -40 & -40 & -40 & -40 & -40 & -40 & -40 \\
\hline Purge time $(\mathrm{s})$ & 3600 & 3600 & 3600 & 1200 & 600 & 300 & 90 & 45 & 0 \\
\hline
\end{tabular}

- Cold start PEMFC. In order to get a quick cold start, stack was run on potentiostatic mode and with a small cooling loop to warm it up quickly.

- Polarisation curve was repeated to get same reference points, thus measuring the performance degradation due to the freezing temperatures.

\subsubsection{Test protocol used with the $100 \mathrm{~W}$ stack}

- Conditioning test at room temperature with wet gases.

- Polarisation curve at room temperature with wet gases.

- Purge procedure. Stack was purged with dry gases (at the cathode air and at the anode $\mathrm{H}_{2}$ ). For that, humidifier is set to a relative humidity of $0 \%$. During the purge procedure, the cathode outlet RH sensor was plugged into the system, when the cathode inlet RH was $10 \%$, to avoid that remaining water in the cathode outlet could condense at the top of the RH sensor, thus falsifying the test results. - Cold storage. The stack was stored in the climate room to the testing temperature and kept there for $12 \mathrm{~h}$.

- Polarisation curve was carried out at room temperature and with wet gases to measure the performance degradation due to the freezing temperatures.

- Conditioning test at room temperature with wet gases. Since the conditioning test is a procedure that can overcome reversible degradation, this test was repeated before carrying out other polarization curve, to prove which performance degradation due to the cold storage was reversible.

- Polarisation curve at room temperature with wet gases.

\section{Results}

\subsection{Cold storage with the $\mathbf{4} \mathrm{kW}$ stack}

This investigation is partly based on prior studies of the purge time influence on the cold start of this $4 \mathrm{~kW}$ stack $[10,11]$. Experimental results showed that the optimal purge time for slow cold starts was an intermediate value, so that membranes can absorb large amounts of water instead of freezing in the cathode catalyst layer (CCL), while being hydrated to guarantee proton conductivity during the cold start [10]. Additionally, a 1-cell cold start model was developed which calculates the ice fraction during cold start at temperatures down to $-40^{\circ} \mathrm{C}$ and was used to study the influence of the purge time on its cold start ability [11]. These simulation results validated the obtained experimentally.

In this study the influence of the cathode purge gas, the purge temperature and the purge time on the PEMFC system performance after cold storage at $-20^{\circ} \mathrm{C}$ were further investigated with the $4 \mathrm{~kW}$ PEMFC system, whose experimental results can be summarized as follows.

\subsubsection{Cathode purge gas}

Tests were carried out purging the cathode before cooling down the stack at $-20^{\circ} \mathrm{C}$ with different gas compositions: synthetic air $\left(\mathrm{O}_{2} 20.9\right.$ Vol.-\%, $\quad \mathrm{N}_{2} 79.1$ Vol.-\% $)$, compressed air and pure nitrogen. During cold storage stack is soaked with dry gases which can diffuse form cathode to anode, and vice versa (fuel and oxidant crossover). Thus, purging the cathode with air may lead to an air-hydrogen front that could cause material and performance degradation [4]. However, by comparing polarization curves was found neither any difference between different gases used, nor performance degradation. Therefore, and for technical reasons compressed air was defined as purge cathode gas for next tests as well as for the later study with the $100 \mathrm{~W}$ stack.

\subsubsection{Purge temperature}

The purge temperature has an effect on the amount of water removed: a higher temperature can be beneficial to take off more water, but the contrary would result from too high temperature $[8,12]$. Test results of varying purge temperature from $+15^{\circ} \mathrm{C}$ to $+50^{\circ} \mathrm{C}$ didn't show any relevant influence, neither on the $4 \mathrm{~kW}$ PEMFC system performance degradation after cold storage nor on its cold start ability. But purging with a high-power size stack at high temperatures (e.g. $\left.+85^{\circ} \mathrm{C}\right)$ may result in a nonuniform drying, thus potential membrane damage $[4,12]$. For this reason, and in order to increase the energy efficiency of the system by eliminating the energy consumed by gas heaters, the purge procedure in the next study with the $100 \mathrm{~W}$ stack was carried out at $+25^{\circ} \mathrm{C}$.

\subsubsection{Purge time}

The purge time influences the water remaining in the stack membranes. These experimental results showed, that the purge time influence on the cold start time of the PEMFC system was lower for quick cold starts than for the slow ones. Moreover, no performance degradation was measured after more than 70 cold starts by purging for $3 \mathrm{~min}$ (intermediate-low value) $400 \mathrm{nl} / \mathrm{min}$ of air in the cathode and $30 \mathrm{nl} / \mathrm{min}$ of $\mathrm{H}_{2}$ in the anode before freezing the stack at $-20^{\circ} \mathrm{C}$, while parasitic loses during shut-down were a bit lower.

\subsection{Cold storage with the $100 \mathrm{~W}$ stack}

\subsubsection{Purge gases flow rates}

Purge gases volume flow rates and optimal purge time (intermediate-low value) previously selected for the $4 \mathrm{~kW}$ stack have been taken as reference to calculate the purge gases flow rates and time for the $100 \mathrm{~W}$ stack, even 
though both stacks have different power sizes and fuel cell components, hence different water storage capacities. According to this estimation, the $100 \mathrm{~W}$ stack should be purged before freezing at $-20^{\circ} \mathrm{C}$ for $90 \mathrm{~s}$ with air in the cathode at $20 \mathrm{nl} / \mathrm{min}$ and with $\mathrm{H}_{2}$ in the anode at $1.5 \mathrm{nl} / \mathrm{min}$. Therefore, in this study the cathode flow rate by purging was varied between 5 and $20 \mathrm{nl} / \mathrm{min}$, as the cathode MFCs maximal flow rate is $10 \mathrm{nl} / \mathrm{min}$, and hence the anode flow rate between 0.375 and $1.5 \mathrm{nl} / \mathrm{min}$.

Figure 2 presents the evolution over time of the cathode relative humidities inlet and outlet $(\mathrm{RH})$ at different purge gases flow rates. As Figure 2 shows, cathode outlet relative humidity decreases proportionally as the flow rate increases, thought this decrease is not linear. Indeed, cathode relative humidities decreased much faster with cathode purge volume flow rates equal to or higher than $10 \mathrm{nl} / \mathrm{min}$. Since the cathode outlet was dried faster by purging with air in the cathode at $20 \mathrm{nl} / \mathrm{min}$ and with $\mathrm{H}_{2}$ in the anode at $1.5 \mathrm{nl} / \mathrm{min}$, this combination was selected for next series of tests. Moreover, and based on the previous results with the $4 \mathrm{~kW}$ stack, we suppose that the optimal purge time $\left(\mathrm{t}_{\mathrm{opt}}\right)$ for the $100 \mathrm{~W}$ stack is not bigger than the corresponding time of the turning point, in which the cathode outlet RH begins to decrease slowly. For the $100 \mathrm{~W}$ stack this RH value was below $20 \%$ for all purge gas combinations, as illustrated in Figure 2. We assume that at this point no relevant water was remaining neither in the channels, nor in the gas diffusion layers (GDL), and that most of the water remaining in the cells is in a non-freezable state at the cold storage temperatures. So, purge times longer than $t_{\text {opt }}$ are not necessary to assure no severe damages due to ice-formation during the cold storage. Moreover, by reducing parasitic losses of a very long purging. the energy efficiency of the system increases. To the contrary, the purge time should be long enough, so that no relevant water remains in the system that can turn into ice, thus damaging the stack and/or other components. Therefore, we expect that the minimal purge time should be the turning point in which the cathode inlet RH begins to decrease slowly. These assumptions were studied in the next series of tests.

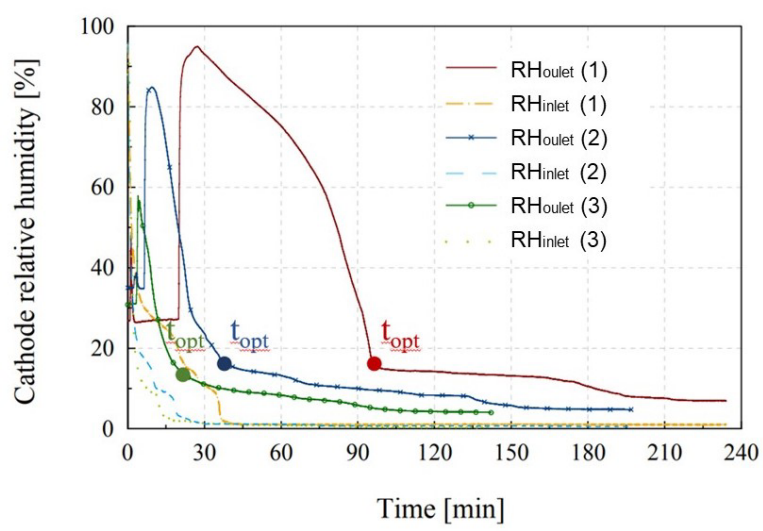

Fig. 2. Cathode relative humidities (inlet and outlet) over time during purge procedure for different combination of gases volume flow rates: (1) $5 \mathrm{nl} / \mathrm{min}$ of air and $0.375 \mathrm{nl} / \mathrm{min}$ of $\mathrm{H}_{2}$, (2) $10 \mathrm{nl} / \mathrm{min}$ of air and $0.75 \mathrm{nl} / \mathrm{min}$ of $\mathrm{H}_{2}$, and (3) $20 \mathrm{nl} / \mathrm{min}$ of air and $1.5 \mathrm{nl} / \mathrm{min}$ of $\mathrm{H}_{2}$.

\subsubsection{Cold storage temperature and purge time}

To illuminate the impact of the cold storage and purge time on the performance degradation of a PEMFC system due to cold storage at temperatures down to $-40^{\circ} \mathrm{C}$, nine $\mathrm{F} / \mathrm{T}$ cycles listed in Table 2 were conducted with different cold storage temperatures and purge times.

Figure 3 illustrates the effect of the first cold storage (test number 1 of Table 2) on the stack performance degradation by comparing the voltage (Fig. 3(a)) and the power density (Fig. 3(b)) as a function of current density before and after the first F/T cycle, as well as after a later conditioning test.
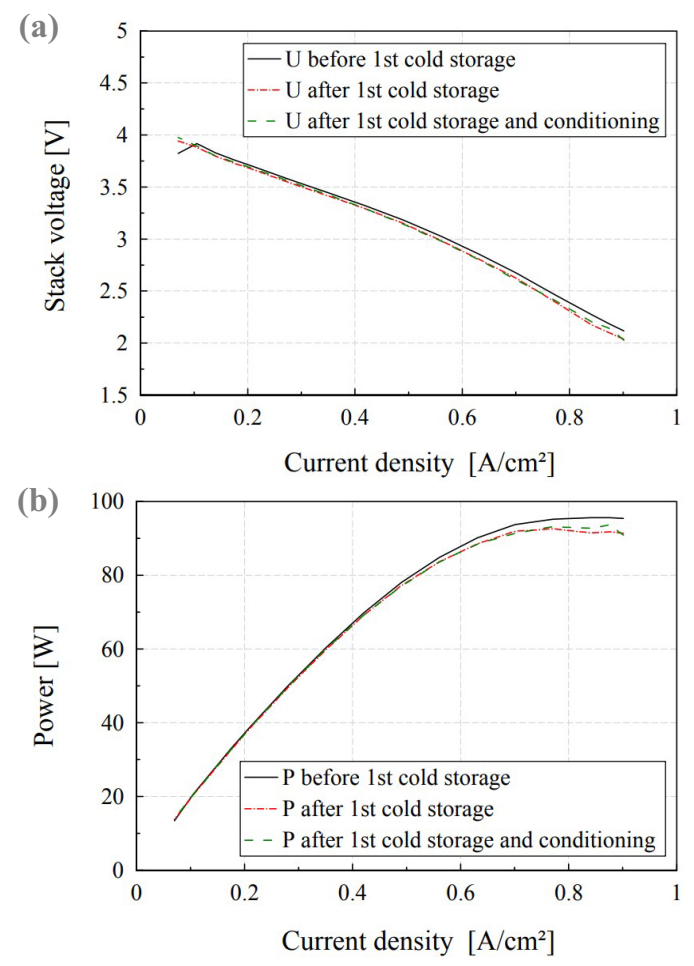

Fig. 3. Effect of the first cold storage at $-10^{\circ} \mathrm{C}$ on the $100 \mathrm{~W}$ stack performance: (a) polarization curves; (b) p-j curves.

As Figure 3 shows, the stack already experienced irreversible performance degradation after the first cold storage, even though it was at a not very low temperature $\left(-10^{\circ} \mathrm{C}\right)$. This degradation may have occurred due to the ice formation during cold storage, but it might be most likely due to the long purging procedure carried out $(1 \mathrm{~h})$. This performance losses may be caused mainly by two factors; the large period at open circuit voltage (OCV) during the purge procedure, and by the excessive dryness of the cells, which may cause an uneven stress distribution in the membrane, thus resulting in membrane degradation $[4,12]$. By operating the stack at OCV can cause fuel and oxidant crossovers as well as cells reversal, which would lead to a higher $\mathrm{CO}_{2}$-corrosion, thus degrading the cells irreversibly [13-15].

Figure 4 compares the polarization and power density curves of the $100 \mathrm{~W}$ stack before and after F/T cycles from Table 2 at different purge times and cold storage temperatures. Specifically, from before the $1^{\text {st }}$ cold storage at $-10^{\circ} \mathrm{C}$ after purging $1 \mathrm{~h}$, to after the $7^{\text {th }}$ cold storage at $-40^{\circ} \mathrm{C}$ after purging $90 \mathrm{~s}$. 
(a)

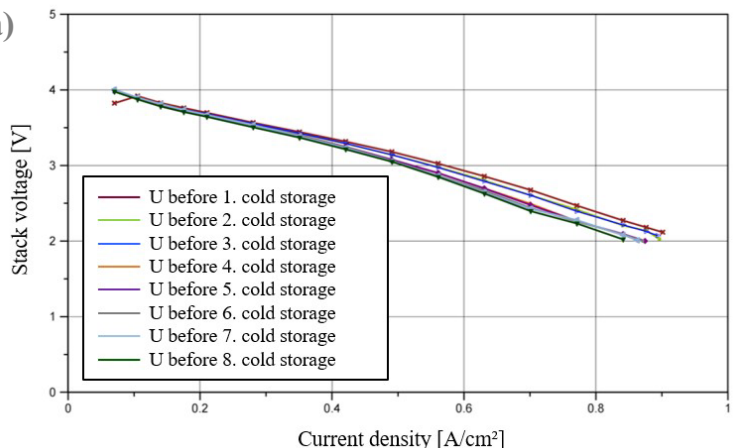

(b)

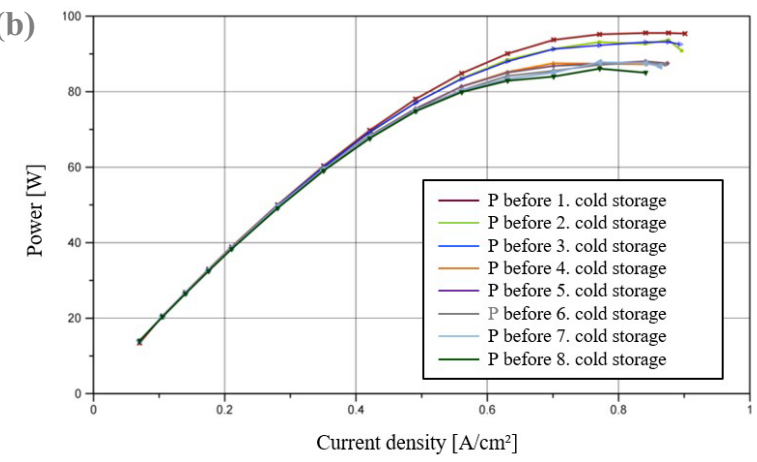

Fig. 4. Effect of the F/T cycles from Table 2 on the $100 \mathrm{~W}$ stack performance: (a) polarization curves; (b) $p-j$ curves.

As Figure 4 illustrates, the greatest performance losses result from the firsts cold storages at $-10^{\circ} \mathrm{C}$ and at $-40^{\circ} \mathrm{C}$, which both have the longest purging procedure $(1 \mathrm{~h})$. This indicates that the performance losses are likely to be influenced more by the long purging than to the freezing temperatures. Therefore, a purge time between 1.5 and $10 \mathrm{~min}$ seems to be more adequate for the $100 \mathrm{~W}$ stack, since a shorter purging reduces degradation and parasitic losses. Thus, the durability and energy efficiency of the PEMFC system can be increased. These results validate our previous assumption of optimal purge time (section 3.2.1.), and are in agreement with the results obtained for the $4 \mathrm{~kW}$ stack, in which the optimal purge time was defined as $3 \mathrm{~min}(400 \mathrm{nl} / \mathrm{min}$ air at the cathode, $30 \mathrm{nl} / \mathrm{min} \mathrm{H}_{2}$ at the anode). Moreover, and according to Figure 2, after purging $10 \mathrm{~min}$ the $100 \mathrm{~W}$ stack $\left(20 \mathrm{nl} / \mathrm{min}\right.$ air at the cathode, $1.5 \mathrm{nl} / \mathrm{min} \mathrm{H}_{2}$ at the anode), the cathode outlet relative humidity was approximately $20 \%$. Which is also in concordance with the experimental results obtained by St-Pierre et al. [12].

By comparing performance curves before and after a $\mathrm{F} / \mathrm{T}$ cycle at $-40^{\circ} \mathrm{C}$ without purging (test $9(\mathrm{G})$ from Table 2), performance losses due to ice formation were observed, specially at current densities higher than $0.75 \mathrm{~A} / \mathrm{cm}^{2}$. These losses were mostly irreversible, not being recovered even after some conditioning tests. But these losses were lower than expected. A possible reason for that may be that the stack operated with an excess oxygen ratio of 3 at low current densities (lower than $0.1 \mathrm{~A} / \mathrm{cm}^{2}$ ) for the last twenty minutes of the polarization curve. Therefore, the stack was already partly dried before freezing without conducting any purge procedure. This shows, that combining the purge procedure with the previous operation of the PEMFC system would be optimal to reduce time and energy consumption.

\section{Conclusions}

In this investigation, the impact of the purge procedure and the cold storage on the performance of two types of PEMFC fuel cell systems has been studied. The main findings of this experimental work are addressed below.

Results showed that the purge temperature required didn't seem to be necessary at a high temperature. Indeed, a higher temperature may lead to a non-uniform drying, thus accelerating membrane degradation $[4,12]$. Hence, this temperature was chosen according to the system at room temperature, thus reducing parasitic losses and consequently enhancing the energy efficiency of the system.

Purge shutdown procedure has to be chosen very carefully. This study has shown that very long purging (e.g. more than $20 \mathrm{~min}$ for the $100 \mathrm{~W}$ stack) also lead to degradation, even at not very low temperatures, such as $-10^{\circ} \mathrm{C}$. This degradation may have occurred because of the large period at $\mathrm{OCV}$ and by the excessive dryness of the cells. Besides, a purging procedure that dries the cells completely would be extremely slow and energy inefficient because of the parasitic losses. Therefore, the optimal purge time is the one reducing remained water in the cells to a value below that at which damage occurs, but not too long to avoid membrane degradation due to internal stress generation. For the $100 \mathrm{~W}$ stack, the optimal purge time was found to be between $1.5 \mathrm{~min}$ and $10 \mathrm{~min}$ by purging $20 \mathrm{nl} / \mathrm{min}$ air at the cathode and $1.5 \mathrm{nl} / \mathrm{min}$ of $\mathrm{H}_{2}$ at the anode. This is in relation with the results obtained with the $4 \mathrm{~kW}$ stack.

Very long purging procedures with air at the cathode and $\mathrm{H}_{2}$ at the anode led to degradation, which may be caused due to fuel and oxidant crossover. For this reason and to enhance the safety and fuel cell efficiency of the system, eliminating anode purge or drying it with nitrogen should be consider.

In addition, the use of a microporous layer (MPL), material choice, cell components design (e.g. diffusion media thickness or channel/land) and the use of a methanol solution as antifreeze during cold storage can help to mitigate degradation due to ice formation $[4,16,17,18]$. With the aim of reducing the degradation due to subfreezing temperatures of a PEMFC system for aircraft applications, these findings will be validated with a state-of-the-art stack, for which cold storages down to $-40^{\circ} \mathrm{C}$ will be carried out. The design of this state-of-theart stack together with the purge procedure are expected to reduce degradation due to ice-formation during cold storage.

This work was financially supported by the Federal Ministry of Transport and Digital Infrastructure of Germany within the framework of the BILBO project (No 03B10701C) and, by the Fuel Cells and Hydrogen 2 Joint Undertaking within the framework of the INN-Balance project (No 735969). This Joint Undertaking receives support from the European Union's Horizon 2020 research and innovation programme, Hydrogen Europe and Hydrogen Europe research. The authors would like to thank Stefan Bleeck and Vincent Hackstein for the set up hardware and software of the $100 \mathrm{~W}$ fuel cell test bench, as well as Dr. Johannes Schirmer for fruitful discussions. 


\section{References}

1. https://www.iea.org/

2. D S Lee, et al., Atmos. Environ. 244, 117834 (2021)

3. H Webber, S Job. (2021). https://www.ati.org.uk/

4. M M Mench, E C Kumbar, T N Veziroglu, Polymer electrolyte fuel cell degradation, (Elservier, Oxford; 2012)

5. E Pinton, L Antoni, Y Fourneron, S Rosini, ECS Trans. 17, 251 (2009)

6. S-Y Lee, et al., J Power Sources. 180, 784 (2008)

7. S Kim, C Chacko, R Ramasamy, M M Mench, ECS Trans. 11, 577 (2007)

8. $\mathrm{P} \mathrm{Xu}, \mathrm{S} \mathrm{Xu}, \mathrm{SAE}$ Int. 01,1312 (2018)

9. G Montaner Ríos, J Schirmer, C Gentner, J Kallo, Appl. Energy. 279, 115813 (2020)

10. G Montaner Ríos G, J Schirmer, J Kallo, EFC (2017)
11. M Schröder, C Gentner, G Montaner Ríos, F Becker, S Bleeck, I Sokolov, J Kallo, MODVAL (2019)

12. J St-Pierre, J Roberts, K Colbow, et al., J. New Mater. Electrochem. Syst. 8, 163 (2005)

13. P Reng, P Pei, Y Li, Z Wu, D Chen, S Huang. Prog. Energy Combust. Sci. 80, 100859 (2020)

14. N Dyanti, A Parsons, P Bujlo, S Pasupathi, Mater Renew Sustain Energy. 8, 4 (2019)

15. S Kundu, M Fowler, L Simon, R Abouatallah, N Beydokhti, J Power Sources. 183, 619 (2008)

16. A Turhan, K Heller, J S Brenizer, M M Mench, J Power Sources. 180, 773 (2008)

17. F Knorr, D Garcia Sanchez, J Schirmer, P Gazdizcki, K A Friedrich, Appl. Energy. 238, 1 (2019)

18. G Montaner Ríos, J Schirmer, F Becker, S Bleeck, C Gentner, J Kallo, ECS Trans. 98, 243 (2020) 